\title{
RADIOISOTOPES LABORATORY RADIOCARBON DATE LIST I
}

\author{
A J SUMODI \\ Dicar Corporation, Cleveland, Ohio 44116 \\ INTRODUCTION
}

The Radioisotopes Laboratory was established in January 1972, in order to supply radiocarbon measurements of various samples to several institutions. Active analyses commenced in June following the testing and evaluation of equipment and known samples for accuracy and reproducibility. During this time, data was accumulated for the statistical establishment of counting accuracy, particularly for background activity.

The laboratory utilizes liquid scintillation counting techniques for radiocarbon analysis through conversion of sample carbon to benzene. The underlying principles in the synthesis techniques are those developed by Noakes et al, $(1965 ; 1967 ; 1971)$ without major modifications. A vanadium-alumina catalyst (Task) is used at reduced temperature for the acetylene to benzene conversion.

The radiocarbon-containing benzene sample is mixed with the scintillator solution and counted in one of 3 Picker Nuclear Corporation Liquimat 220 liquid scintillation spectrometers. Counting time is dependent on estimates sample age and is usually 4000-5000 mins. Age calculations are routinely performed on a Wang Model 450 programmable electronic calculator.

\section{LABORATORY OPERATIONS}

Samples are routinely inspected under $20 \mathrm{X}$ illuminated magnification for obvious impurities (rootlets, leaves, bush bristles, etc) and are prepared for chemical removal of contaminants. Unless otherwise indicated, all samples are routinely pretreated even when no contamination is evident.

A charcoal or wood sample free of rootlets is broken into fragments 2 to $3 \mathrm{~cm}$ long and 5 to $6 \mathrm{~mm}$ thick, treated with $2.0 \mathrm{~N} \mathrm{NaOH}$ at room temperature and stirred for $24 \mathrm{hrs}$, filtered, washed and treated in boiling $2.0 \mathrm{~N} \mathrm{NaOH}$ for $3 \mathrm{hrs}$. Filtering and boiling are repeated with the sample receiving an additional final base soak at room temperature for 48 hrs. The sample is then stored in $2.0 \mathrm{~N} \mathrm{HCl}$ for 48 hrs for carbonate removal and minimization of atmospheric carbon dioxide uptake. Washing to neutrality with distilled water completes the procedure.

If rootlet contamination is suspected, the standard base treatment is augmented by slightly modified procedures (Michael and Ralph, 1970). The charcoal is placed in concentrated $\mathrm{HCl}(18 \mathrm{M})$ followed by slow addition, with stirring, of $\mathrm{NaOCl}$, and remains in solution overnight. Next follows thorough washing and nitration in a 1:1 mixture of concentrated $\mathrm{HNO}_{3}, \mathrm{H}_{2} \mathrm{SO}_{4}$ for $2 \mathrm{hrs}$ at room temperature. The residue is 
washed to neutrality and extracted with $\left(\mathrm{CH}_{3}\right)_{2} \mathrm{CO}$ until no further soluble material remains. Washing in distilled water completes the process.

The same procedures used for charcoal are employed for wood, with decreased solution times and approximate doubling of sample quantities. The wood is oxidized for $1 / 2 \mathrm{hr}$ while nitration is continued for a maximum of 20 mins. Longer duration reduces significant quantities of useful sample as discussed by Loudon (1969).

After establishing relative peat insolubilities in base solutions, samples are treated in $0.2 \mathrm{~N} \mathrm{NaOH}$ for 30 mins at room temperature, washed to neutrality, and placed in $1.0 \mathrm{~N} \mathrm{HCl}$ at room temperature for 15 mins. A final washing follows.

Prior to chemical pretreatment, shells are scoured with a stiff brush and ultrasonically washed for 5 mins when possible. Sample size permitting, ca $20 \%$ of outer shell layer is removed by acid leach using a quantity of concentrated $\mathrm{HCl}$ at room temperature equal to 0.33 times the weight of shell in grams (Loudon, 1973, pers. commun). The residue is then filtered and washed to neutrality in distilled water.

Bone is routinely processed and analyzed according to Krueger (1965) and Haynes (1967) for dating bone collagen with slight modifications. Whereas acid concentration is maintained at $1.0 \mathrm{~N}$ bone decomposition continues under refrigeration at $10^{\circ} \mathrm{C}$ permitting recovery of more collagen. After filtration and washing, the residue is treated with cold 1.0N NaOH for $2 \mathrm{hrs}$ prior to combustion.

Various types of foraminifera ... shells and carbonate oozes are routinely treated with $\mathrm{NaOCl}$ at room temperature overnight after crushing. The submitter is asked to separate the core material to minimize contamination.

Table 1 gives the suggested minimum quantities for analysis.

TABLE 1

Minimum suggested sample quantities

\begin{tabular}{ll}
\hline Material & Amount $(\mathrm{g})$ \\
\hline charcoal & 10 \\
wood & 10 \\
peat & $25-35$ \\
bone & $300-500$ \\
shell & $100-150$ \\
foram* & $8-10$ \\
\hline
\end{tabular}

* sample weight less core material

Purified samples are routinely converted to benzene using the methods of Noakes et al, (1965) with ancillary improvements in techniques. Lithium is supplied by the Lithium Corporation of America (Lithcoa) in dry packed shot form, and refrigerated until used. The possibility of carbon dioxide decomposition to carbon is avoided as 
indicated by Polach (1967) by permitting small quantities of the sample $\mathrm{CO}_{2}$ to be "pulsed" into the lithium chamber. At no time is the pressure of the $\mathrm{CO}_{2}$ allowed to build up. The lithium carbide mixture is heated to $900^{\circ} \mathrm{C}$ for $1 \mathrm{hr}$ and evacuated to insure complete conversion and effective radon removal.

Benzene yields may be improved if a dry ice-isopropyl alcohol bath is placed around the catalyst column during acetylene introduction. This results in a negligible production of ethylbenzene and a more uniform utilization of the entire catalyst column during trimerization. These techniques have been found to yield 1 to $3.0 \mathrm{~g}$ pure benzene from an $8 \mathrm{~g}$ carbon sample.

The sample benzene is placed in tared, low potassium vials, from the Packard Corporation (Packard) and adjusted to a final volume of $10 \mathrm{ml}$ with spectrophotometric grade benzene. Four $\mathrm{ml}$ aliquots of a scintillation solution containing $6.250 \mathrm{~g}$ PPO and $0.624 \mathrm{~g}$ POPOP in $500 \mathrm{ml}$ spectrophotometric grade benzene is added to the sample and dark adapted for 30 mins prior to counting. Sample counts are accumulated for 4 to 6000 mins depending upon estimated sample age.

Sample activity is determined in 1 of 3 Picker dual channel liquid scintillation spectrometers operated in the coincidence mode and maximized for exclusion of tritium counts. Discriminator settings are adjusted for ${ }^{14} \mathrm{C}$ activity isolation and calibrated to accept a moderate range of quenching action through external standards channels ratio. Although it has been found that little, if any, ${ }^{14} \mathrm{C}$ quench occurs, samples are routinely checked and compared with background information for any significant discrepancy. Table 2 gives the pertinent information for each counter.

TABle 2

\begin{tabular}{|c|c|c|c|}
\hline \multirow[b]{2}{*}{ Property } & \multicolumn{3}{|c|}{ Counter } \\
\hline & I & II & III \\
\hline${ }^{14} \mathrm{C}$ activity $\left(\mathrm{cm}^{-1} \mathrm{~g}^{-1}\right)$ & 6.629 & 7.025 & 6.631 \\
\hline Efficiency $(\%)$ & 60.58 & 59.65 & 60.28 \\
\hline Figure of merit* & 452 & 440 & 421 \\
\hline Window** & $350-625$ & $300-600$ & $325-600$ \\
\hline${ }^{3} \mathrm{H}$ efficiency & 26.23 & 23.09 & 24.11 \\
\hline Window** & $0.050-0.114$ & $0.040-0.116$ & $0.050-0.120$ \\
\hline $\begin{array}{l}\text { Average background } \\
\qquad\left(\mathrm{cm}^{-1} \mathrm{~g}^{-1}\right)\end{array}$ & $8.430 \pm 0.029$ & $8.011 \pm 0.027$ & $8.481 \pm 0.028$ \\
\hline
\end{tabular}

* Defined as $\mathbf{E}^{2} / \mathbf{B}$ where $\mathbf{E}=$ efficiency, $\mathbf{B}=$ background.

** Lower and upper discriminator settings, respectively.

Fluctuations in the number of accumulated counts due to vial activity are minimized by counting "background" in the same vial with 
the same volume composition as used for sample analysis. Thorough cleaning prevents any interference from residual sample activity. Backgrounds are accumulated for 2 to $3000 \mathrm{mins}$ and averaged with the accumulated total for age calculations. Table 3 gives the average monthly background activity as presently established.

TABle 3

Average monthly background activity

(in cpm)

\begin{tabular}{rccc}
\hline Month & Counter I & Counter II & Counter III \\
\hline 1972-Oct & $8.860 \pm 0.043$ & $7.927 \pm 0.026$ & $8.420 \pm 0.025$ \\
Nov & $8.890 \pm 0.026$ & $8.266 \pm 0.017$ & $8.738 \pm 0.026$ \\
Dec & $8.657 \pm 0.020$ & $8.591 \pm 0.025$ & $8.654 \pm 0.023$ \\
1973-Jan & $8.178 \pm 0.027$ & $8.262 \pm 0.040$ & $8.429 \pm 0.039$ \\
Feb & $8.105 \pm 0.041$ & $7.273 \pm 0.024$ & $8.597 \pm 0.030$ \\
Mar & $8.172 \pm 0.022$ & $7.573 \pm 0.033$ & $8.590 \pm 0.022$ \\
Apr & $8.151 \pm 0.023$ & $8.140 \pm 0.022$ & $8.644 \pm 0.029$ \\
Average & $8.430 \pm 0.029$ & $\overline{8.011 \pm 0.027}$ & $\overline{8.581 \pm 0.028}$ \\
\hline
\end{tabular}

A slight adjustment was made with the discriminator settings of Counter II in February and again in April to analyze certain characteristics of the photomultiplier tubes. For this reason the apparent changes in averaged monthly background counts are shown in the table.

Calculations are affected using 95\% activity of NBS 1950 oxalic acid with an accepted half-life of $5568 \pm 30 \mathrm{yr}$ as recommended by the editors of radiocarbon. The associated error of each age includes the uncertainty in sample, background, and standard counts but does not include the half-life uncertainty. Numbers are reported to the nearest decade.

Benzene conversion of the oxalic acid standard is effected by "wet" oxidation techniques with, at present, no corrections made for isotope fractionation. Determination of standard specific activity is routinely performed once a month and averaged with an associated background accumulation of the existing data.

Submitted reports involve the printer tabulation of accumulated sample and background counts, a duplicate report detailing chemical pretreatment and procedures steps, and a calculation sheet detailing age determinations based on $2 \sigma$ criterion. For date list publications, these values have been converted to $1 \sigma$.

Analysis of samples dated by other sources, is a continuing activity and is performed whenever time and spectrometer availability permit. Table 4 presents the ages determined for various check samples from various sources as currently established. 
TABle 4

Results of check sample analyses

\begin{tabular}{lcccc}
\hline \multicolumn{2}{c}{ Radioisotopes laboratory } & \multicolumn{2}{c}{ Other labs } \\
Sample & $\begin{array}{c}\text { Sample } \\
\text { no. }\end{array}$ & Age & $\begin{array}{c}\text { Sample } \\
\text { no. }\end{array}$ & Age \\
\hline Charcoal & DIC-4 & $1645 \pm 90$ & M-2217 & $1570 \pm 110$ \\
& & & Wis-537 & $1640 \pm 50$ \\
Wood & DIC-5 & $12,200 \pm 200$ & UGa-441 & $12,275 \pm 230$ \\
Wood & DIC-6 & $26,000 \pm 800$ & UGa-442 & $26,620 \pm 600$ \\
Wood & DIC-8 & $22,020 \pm 650$ & UGa-443 & $21,120 \pm 290$ \\
\hline
\end{tabular}

\section{ACKNOWLEDGMENTS}

Acknowledgment is made to David Brose, Department of Anthropology, Case Western Reserve University for interpretations and criticisms of archaeologic dates; Samuel Savin and Francis G Stehli, Department of Geology, Case Western Reserve University for help with geologic samples; and Donald Kearns, Picker Nuclear Corp, for immeasurable assistance in laboratory set-up and operation.

\section{SAMPLE DESCRIPTIONS \\ I. ARGHAEOLOGIC SAMPLES}

\section{Michigan}

\section{A. United States}

\section{DIC-1. Indian Trails}

Human bone from ossuary, Late Woodland Younge tradition multiple reburial. Sample from Indian Trails site (20 MR 4), sand ridge (alt $180 \mathrm{~m}$ ) on $\mathrm{S}$ bank of Stoney Creek, Exeter Twp, Monroe Co, Michigan $\left(42^{\circ} 0^{\prime} 30^{\prime \prime} \mathrm{N}, 83^{\circ} 47^{\prime} 30^{\prime \prime} \mathrm{W}\right)$. Sample is probably remains of 3 individuals (cranial, pelvic fragments) assoc with a sealed burial pit with ceramics of Macomb Linear and Springwells Net Impressed types. Coll by $\mathrm{R}$ Patton; subm by $\mathrm{D}$ Brose, Anthropol Dept, Case Western Reserve Univ, Cleveland, Ohio.

\section{DIC-13. Fisher Lake}

$880 \pm 100$

Human bone from Feature 2, Fisher Lake site, $\mathrm{N}$ shore of Big Glen Lake at outlet to Crystal R $3 \mathrm{~km} \mathrm{~S}$ of Lake Michigan, Lelanau Co, Michigan $\left(45^{\circ} 0^{\prime} \mathrm{N}, 83^{\circ} 0^{\prime} \mathrm{W}\right)$. Sample from sealed storage pit on low sand ridge. Matrix consists of fish bone, elk bone, and cultural material including small corner-notched points of local Eastport cherts and ceramics similar to Bois Blanc Braced Rim and Hein's Greek CordedStamped types. Coll and subm by D and B Brose. 
Human bone from salvage operation on S edge of Tuttle Hill site, Trench D, and composed of bluff top village and burial complex on W bank of Cuyahoga R, Cuyahoga Co, Ohio. Area should relate to Tuttle Hill site (Greenman, 1937) 200m N. Sample represents pit burial assoc with both small corner-notched and triangular points. Assoc ceramics include types analogous to Baum Cord-marked (Griffin, 1943), Anderson Incised (Griffin, 1943), Fairport Plain (Fitting, 1964), Mixter Dentate (Shane, 1967). Coll and subm by D Brose. Comment: pit represents earliest occupation of site.

\section{DIC-19. Chagrin River}

Tree branch, possibly red oak, from Chagrin R alluvium, Eastlake, Ohio, alt $200 \mathrm{~m},\left(40^{\circ} \mathrm{N}, 81^{\circ} 26^{\prime} \mathrm{W}\right)$ at depth $5 \mathrm{~m}$. Root ends oriented uniformly westward. Observed at center of $\mathrm{E}$ wall of excavation, overlain by silt, yellow river gravel and sand, black river gravel and sand. Subm by D Brose.

\section{DIC-21. Chagrin River}

$870 \pm 60$

Tree branch, possibly poplar, from Chagrin R alluvium, Eastlake, Ohio at depth 5m (cf DIC-19, above). Subm by D Brose. Comment: sample underlies Early Whittlesey phase occupation.

\section{DIC-33. Gladieux site, Unit 1, Pit 1}

$1930 \pm 60$ AD 20

Charcoal, from bluff habitation site along $\mathrm{N}$ shore of Maumee $\mathrm{R}$, Lucas $\mathrm{Co},\left(41^{\circ} 35^{\prime} \mathrm{N}, 83^{\circ} 37^{\prime} \mathrm{W}\right), 25$ to $31 \mathrm{~cm}$ below surface of cultural pit from single component site, clay. Cultural material typically Western Basin Middle Woodland, similar to material from North Bass Island burial mound. Coll by E J Prahl; subm by D M Stothers, Anthropol and Sociol Dept, Univ Toledo, Toledo, Ohio.

\section{Doctor's Site series}

DIC-40. Doctor's site, No. 1-C

$$
\begin{array}{r}
780 \\
\text { AD } 1170
\end{array}
$$

Charcoal from stratum representing single cultural occupation. Sample from test pit in midden deposit, 15 to $45 \mathrm{~cm}$ below surface along $\mathrm{S}$ side of Ottawa Creek in Lucas Co, Point Place, USGS $71 / 2^{\prime}$ quad $\left(41^{\circ} 42^{\prime} \mathrm{N}, 83^{\circ} 30^{\prime} \mathrm{W}\right)$. Sample denotes Late Woodland provenience culturally related to Peter's phase of Cole horizon. Coll by E J Prahl; subm by D M Stothers.

\section{DIC-34. Doctor's site, No. 2-C}

$$
\begin{array}{r}
670 \pm 65 \\
\text { AD } 1280
\end{array}
$$

Charcoal from stratum representing single cultural occupation of site No. 2-C ( $c$ DIC-40, above). Coll by E J Prahl, subm by D M Stothers. 
DIC-39. Doctor's site, No. 3-C

Charcoal from stratum representing single cultural deposit (cf DIC-40, above). Coll by E J Prahl; subm by D M Stothers.

\section{Waterworks Burial Mound series}

DIC-51. Waterworks Burial Mound, No. 1-A AD 830

$1120 \pm 55$

Charcoal, burnt twigs, from hearth feature at base of burial mound, matrix of clayey silt. Feature H2/Sq 1, Lucas Co, Ohio, Reno Beach, USGS $71 / 2^{\prime}$ quad $\left(41^{\circ} 41^{\prime} \mathrm{N}, 83^{\circ} 18^{\prime} \mathrm{W}\right)$, representing Middle Woodland to Late Woodland transition. Coll and subm by D M Stothers.

\section{DIC-36. Waterworks Burial Mound, No. 2-A}

$1460 \pm 55$

Charcoal in clayey silt from exploratory trench at base of burial mound, assoc with partially charred human skeleton. Feature $\operatorname{Tr} \mathrm{Du} 1$, $\left(41^{\circ} 41^{\prime} \mathrm{N}, 83^{\circ} 18^{\prime} \mathrm{W}\right.$ ) (cf DIC-51, above). Coll by E J Prahl; subm by D M Stothers.

DIC-48. Waterworks Burial Mound, No. 3-A

$1460 \pm 55$

Charcoal and clayey silt from fill encompassing a flexed burial at base of mound. Feature Sq 3/Bu $2\left(41^{\circ} 41^{\prime} \mathrm{N}, 83^{\circ} 18^{\prime} \mathrm{W}\right)(c f$ DIC-51, above). Coll and subm by D M Stothers.

DIC-37. Williams site, No. 1-D

$590 \pm 75$

Charcoal from refuse pit, 15 to $30 \mathrm{~cm}$ below subsoil in sandy silt on edge of Maumee $\mathrm{R}$ flood plain, $\mathrm{S}$ of Toledo $\left(41^{\circ} 31^{\prime} \mathrm{N}, 83^{\circ} 40^{\prime} \mathrm{W}\right)$ Wood Co, Maumee, USGS $71 / 2^{\prime}$ quad. Assoc artifactual sample considered representative of Upper Mississippian culture. Coll by E I Prahl; subm by D M Stothers.

\section{DIC-60. North Bass Island}

$1410 \pm 65$

Charcoal, possibly cedar, clayey matrix in File C, 0.3 to $0.6 \mathrm{~m}$ below surface, from crypt with assoc cremations, possibly typical of Western Basin Middle Woodland. Mound located on $\mathrm{S}$ central shore of North Bass I in W basin of Lake Erie $\left(41^{\circ} 42^{\prime} \mathrm{N}, 82^{\circ} 49^{\prime} \mathrm{W}\right)$ Ottawa, Co, Put-in-Bay, USGS 71/2' quad. Coll by E J Prahl; subm by D M Stothers.

DIC-50. North Bass Island, No. 2-B

$$
1690 \pm 60
$$
AD 260

Burnt cedar logs from crematory crypt in clayey matrix 0.3 to $0.6 \mathrm{~m}$ below surface of mound near center and base of mound. Sample from North Bass I burial mound ( $c f$ DIC-60, above). Coll by E J Prahl; subm by D M Stothers. 
DIC-42. Patyi-Dowling site, No. 1-G

AD 1470

Charcoal from burial in yellow sand subsoil overlying sandy humus from fill encompassing burial with grave pit below plow zone. Burial

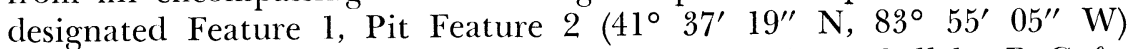
Fulton Co, Ohio. Sample represents Springwells phase. Coll by R Cufr; subm by D M Stothers.

DIC-55. Patyi-Dowling site, No. 2-G

$650 \pm 50$

Charcoal from pit $3 \mathrm{~m}$ from burial containing undefined variant of Macomb Linear ceramics ( $c f$ DIC-42, above). Coll by R Cufr; subm by D M Stothers.

DIC-53. Bone fragments

$2390 \pm 100$

440 BC

Human bone cremation fragments in sandy matrix representing red ocher Archaic cremation with assoc cremation items. Sample from burial pit below plough zone along flood plain of Maumee R $3.2 \mathrm{~km} \mathrm{SW}$ of Fort Meigs $\left(32^{\circ} 30^{\prime} \mathrm{N}, 83^{\circ} 40^{\prime} 15^{\prime \prime} \mathrm{W}\right)$, Wood Co. Coll by Toledo Area Aboriginal Research Club; subm by D M Stothers. Comment: date is slightly more recent than expected and a duplicate sample is being analyzed. Results will be listed later.

\section{Tennessee}

Site 40 series

DIC-28. Site 40 LD-45, No. 254 (F 18)

$1660 \pm 80$

Finely divided charcoal in clayey matrix from Feature 18, shallow basin-shaped fire pit containing several burned quartzite cobbles. Points of origin $0.3 \mathrm{~m}$ below present surface, base of Level II midden $35^{\circ} 45^{\prime}$ $\left.22^{\prime \prime} \mathrm{N}, 84^{\circ} 22^{\prime} 15^{\prime \prime} \mathrm{W}\right)$, Loudon Co. Sample dates Early Woodland occupation of site and adjoining Early Woodland house of same horizon. Coll and subm by M C R McCollough, Anthropol Dept, Univ Tennessee, Knoxville.

DIC-31. Site 40 LD-45, No. 255 ( F 3)

$1700 \pm 13$ AD 250

Finely divided charcoal in loose dark brown sand, very friable, representing central core of fill of Feature 3 , point of origin $0.2 \mathrm{~m}$ below surface, top of Level II midden, plow zone (cf DIC-28, above). Coll and subm by M C R McCollough.

\section{DIC-26. Site 40 LD-45, No. 256 (P H 9)}

$1310 \pm 110$ AD 640

Finely divided charcoal with charred river cane and acorns occurring in S $1 / 2$ of Postmold 9 with present surface base of Level II Midden. Occupation believed to be Early Woodland ( $c f$ DIC-28, above). Comment: ${ }^{14} \mathrm{C}$ age believed more recent than true age. Coll and subm by $\mathrm{M} \mathrm{C} \mathrm{R}$ McCollough. 
DIC-27. Site 40 LD-45, No. 258 (F 12)

Finely divided charcoal in matrix of brown clay, burnt clay, and charcoal from edge of refuse pit (Feature 12) on compacted floor delimited by timber windbreak or shelter. Exact provenience is Feature 7, living floor intercalated between Levels III and IV $0.5 \mathrm{~m}$ below present surface. Date assigned for Level III Midden, Late Archaic occupation and shelter ( $c f$ DIC-28, above). Coll and subm by M C R McCollough.

DIC-30. Site 40 LD-45, No. 259 (F 11)

$2100 \pm 85$

Finely divided charcoal in matrix overlain by secondary fill of dark brown loam from bottom fill of cooking pit (Feature 11). Point of origin $0.5 \mathrm{~m}$ below present surface (base of Level III) and excavated into yellow-brown clay of Level IV, $0.8 \mathrm{~m}$ below present surface ( $c f$ DIC-28, above). Coll and subm by M C R McCollough.

DIC-29. Site 40 LD-45, No. 262

$1550 \pm 95$

Finely divided charcoal in clayey matrix from deep Archaic living floor (Level V) comprising a thin lens $(6 \mathrm{~cm})$ at horizon $1 \mathrm{~m}$ below present surface. Sample intercalated between Level IV and Level VI, and represents earliest occupation of site. Occupation is probably as early as Middle Archaic with possible prehistoric flooding ( $c f$ DIC-28, above). Coll and subm by M C R McCollough. Comment: date is questionable and sample is being reprocessed. Results will be listed later.

\section{Florida}

DIC-44. Cayson West site, No. 1

$$
\begin{array}{r}
940 \\
\text { AD } 1010
\end{array}
$$

Charcoal particles from clay wall, $690 \mathrm{E} 490$ (Feature 3) at 8CA 3 $\left(30^{\circ} 26^{\prime} \mathrm{N}, 85^{\circ} 01^{\prime} \mathrm{W}\right)$ Blountstown, Florida. Coll by J Scarry; subm by $\mathrm{D}$ Brose.

DIC-45. Cayson West site, No. 2

$840 \pm 65$

Charcoal from burnt activity floor $2 \mathrm{~m}$ below present surface of mound. At least 3 subsequent construction stages overlie this floor, and at least 4 such stages underlie it. Profile at edge of platform mound located at 8CA 3 ( $c f$ DIC-44). Coll by T Gray; subm by D Brose.

\section{DIC-46. Cayson West site, No. 3}

$$
770 \pm 60
$$

Charcoal from Level VIII at $495 \mathrm{E} 775$ in grayish silt 0.7 to $1.3 \mathrm{~m}$ below surface. Sample represents refuse midden in basket loads, assoc with Wakulla Check-Stamp, Weeden Island Incised, Fort Walton Incised, and Lake Jackson Plain ceramics. Coll by $\mathrm{P}$ Essenpreis; subm by $\mathrm{D}$ Brose. 
General Comment: DIC-44, -46 should represent a single early Fort Walton occupation.

\section{B. Canada}

DIC-56. East Sugar Island

$$
1890 \pm 60
$$

AD 60

Charcoal from prepared floor of burial mound in ash-clay till. Mound at $\mathrm{S}$ end of East Sugar $\mathrm{I}$ across channel from Serpent mounds $\left(49^{\circ} \mathrm{N}, 79^{\circ} 08^{\prime} \mathrm{W}\right)$, Rice Lake, $31 \mathrm{D} / 1 \mathrm{E}$ quad map Ontario, Canada. Sample represents Middle Woodland occupation. Coll and subm by D M Stothers.

\section{GEOLOGIC SAMPLES}

\section{A. United States}

DIC-52. Olen Pit

30,570 BC

Branch from carbonaceous stratified sand in gravel pit terrace along Big Darby Creek at SE corner of Plain City quad map, Franklin Co,

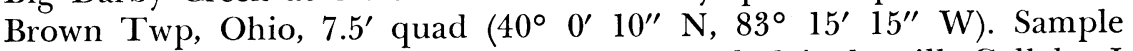
overlain by $1.5 \mathrm{~m}$ till, $10 \mathrm{~m}$ outwash gravel, underlain by till. Coll by $\mathrm{J}$ Antrium; subm by D Fullerton, Ohio Geol Survey, Columbus, Ohio.

\section{DIC-57. Jackson Chapel, RC-2}

$$
\underbrace{26,220^{-4}}_{23,270 \text { BC }}
$$

Wood in silt, weakly calcareous till from $\mathrm{S}$ bank of tributary to Scioto R, .09m SSE of Jackson Chapel Crossroads, Franklin Co, Twp, Commercial Point, $7.5^{\prime}$ quad ( $\left.39^{\circ} 52^{\prime} \mathrm{N}, 83^{\circ} 01^{\prime} 30^{\prime \prime} \mathrm{W}\right)$. Sample overlain by till of similar appearance and composition, and 2 younger sandy tills. Coll and subm by D Fullerton.

\section{DIC-32. Garfield Hts, RC-3, Schloss No. 1}

Unidentified twigs and wood fragments from laminated sand and gravel at W face of inactive gravel pit, 90 to $270 \mathrm{~m} \mathrm{~S} \mathrm{~W} \mathrm{of} \mathrm{Penn} \mathrm{Central}$ crossing on McCracken Blvd, Garfield Hts, Ohio, Cuyahoga Co, Shaker Hts, $7.5^{\prime}$ quad $\left(41^{\circ} 21^{\prime} \mathrm{N}, 81^{\circ} 35^{\prime} \mathrm{W}\right)$. Varved sequence overlain by 3 till units and underlain by silt and Illinoian outwash gravel. Coll and subm by D Fullerton and G Groenwald, Ohio Geol Survey, Columbus, Ohio.

$$
\underbrace{+580}_{23,560}-675
$$

DIC-35. Garfield Hts series, RC-4

Twigs and wood fragments from lower $8 \mathrm{~cm}$ of laminated silt and clay (cf DIC-32, above) $\left(41^{\circ} 25^{\prime} \mathrm{N}, 81^{\circ} 35^{\prime} \mathrm{W}\right)$. Overlain by 2 till units 
and underlain by gastropod-rich silt, greatly decomposed till, and still older Illinoian outwash gravel. Debris deposited in preglacial lake formed in the Millcreek valley during initial ice advance that deposited till overlying lake sediment. Coll and subm by D Fullerton and G Groenwold.

DIC-38. Garfield Hts series, RC-5

Unidentified $\log$ from $W$ wall of gravel pit $35 \mathrm{~m}$ NW of PennCentral crossing $\left(41^{\circ} 25^{\prime} \mathrm{N}, 81^{\circ} 35^{\prime} \mathrm{W}\right)$. Sample enclosed entirely by lake sediment with base resting on upper contact of loess (cf DIC-32). Varves directly overly upper loess and are overlain by silt and Hiram till. Coll and subm by D Fullerton and G Groenwald.

DIC-41. Eaton Cut, RC-6 $-450$

Wood fragments from W Bank of Seven Mile Creek, SE of Frederick Dr, Eaton, Ohio, NW 1/4, SE $1 / 4$ W, 3 T.7N, R 2E $\left(39^{\circ} 44^{\prime} \mathrm{N}, 84^{\circ} 38^{\prime}\right.$ W). Sample from $0.5 \mathrm{~m}$ above base of Fayette till (Thomas, 1970), $6.6 \mathrm{~m}$ thick, overlain by lacustrine-fluvial sediments and complex of younger till units. Coll and subm by R A Struble, Ohio Geol Survey.$$
+\mathbf{5 3 5}
$$$$
\mathbf{2 4 , 4 4 0}
$$ \\ DIC-47. Talawanda Creek, RC-7 \\ 22,490 BC \\ $-615$}

Wood, portion of unidentified $\log$ from $\mathrm{E}$ bank of Talawanda or Fourmile Creek, $4.8 \mathrm{~km} \mathrm{~N}$ of Oxford, NE 1/4, NW 1/4, Sec II, Oxford Twp, Butler Co $\left(39^{\circ} 33^{\prime \prime} \mathrm{N}, 84^{\circ} 44^{\prime} \mathrm{W}\right)$, Ohio. Sample from bedded calcareous sand from U 44 (Durrell, 1961). Coll and subm by R A Struble.

DIC-43. Camden Section, RC-8

$\geqslant 42,000$

Wood fragments from $\log$ in Camden $\mathrm{S}, 3.2 \mathrm{~km} \mathrm{~N}$ Camden, Ohio, Camden morain, Sec 33, Somers Twp, S Eaton quad $\left(39^{\circ} 40^{\prime} \mathrm{N}, 84^{\circ} 39^{\prime}\right.$ W). Sample from tentatively identified Whitewater till, overlain by at least 2 younger tills. Coll by T Agne and M De Wine; subm by R A Struble.

\section{South Pacific}

DIC-17.

$$
\begin{array}{r}
1380 \\
\text { AD } 570
\end{array}
$$

Benthonic Foraminifera (diatom-nannoplankton ooze) in carbonate core, 0 to $6 \mathrm{~cm}$ fraction from top, $\left(54^{\circ} 44.2^{\prime} \mathrm{S}, 120^{\circ} 00^{\prime} \mathrm{W}\right)$ South Pacific Ocean, at depth 1500 fathoms. Coll by A V Eltanin; subm by R Douglas, F Stehli, and S Savin, Geol Dept, Case Western Reserve Univ. 
DIC-12.

$2530 \pm 85$

AD 580

Benthonic Foraminifera ( $c f$ DIC-17), from 3 to $8 \mathrm{~cm}$ depth in core.

\section{DIC-15.}

\section{$10,710 \pm 165$}

876 BC

Benthonic Foraminifera ( $c f$ DIC-17), below top of core.

\section{DIC-11.}

$13,650 \pm 140$

Benthonic Foraminifera ( $c f$ DIC-17), from 24 to $28 \mathrm{~cm}$ depth in core.

\section{DIC-54.}

$15,680 \pm 550$

Benthonic Foraminifera ( $c f$ DIC-17), from 72 to $78 \mathrm{~cm}$ depth in core.

Comment: sample $\mathrm{CO}_{2}$ mixed with "dead' material to increase $\mathrm{O}_{6} \mathrm{H}_{6}$ yield.

\section{REFERENCES}

Durrell, R H, 1961, The Pleistocene geology of the Cincinnati area, Field Trip 3, in: Geol Soc America Guidebook for Field Trips, New York, Geol Soc America, p 47-57.

Fitting, James, 1964, Ceramic relationships of four Late Woodland sites in northern Ohio: The Wisconsin Archaeologist, v 45, p 160-175.

Greenman, E F, 1937, Two Prehistoric villages near Cleveland, Ohio: Ohio State Archacol and Hist Quart, v 46, p 305-366.

Griffin, J E, 1943, The Fort Ancient aspect: Ann Arbor, Michigan, Univ Michigan Press.

Haynes, C V, 1967, Bone organic matter and radioactive dating, in: Symposium of radioactive dating and methods of low level counting, Proc, IAEA, 1967, Vienna, Austria.

Krueger, H W, 1965, Preservation and dating of collagen in ancient bone, in: 6th internatl conf on radiocarbon and tritium dating, Proc, USAEC conf-650652, Pullman, Washington.

Lowdon, J A, Wilmeth, R, and Blake, W, Jr, 1969, Geological Survey of Canada radiocarbon date list VIII: Radiocarbon, $v$ 11, p 22-42.

Michael, H W, and Ralph, E K, 1970, Dating techniques for the archaeologist: Cambridge, Massachusetts, MIT Press, p 15.

Noakes J E, 1971, Modern aspects of liquid scintillation counting, in: Neary, M P (ed), Liquid scintillation: Fullerton, California, Beckman Instruments, Inc, p 8-1$8-22$.

Noakes, J E, Kim, S M, and Akers, L K, 1967, Recent improvements in benzene chemistry for radiocarbon dating: Geochim et Cosmochim Acta, v 31, p 1094-1096.

Noakes, J E, Kim, S M, and Stipp, J J, 1965, Chemical and counting advances in liquid scintillation age dating: 6 th internatl conf on radiocarbon and tritium dating, Proc, USAEC conf-650652, Pullman, Washington.

Polach, H A and Stipp, J J, 1967, Improved synthesis techniques for methane and benzene radiocarbon dating: Jour Appl Radiation and Isotopes, v 18, p 359-364.

Shane, O C, III, 1967, The Mixter site, in: Prufer and McKenzie (eds), Studies in Ohio archaeology: Cleveland, Western Reserve Univ Press, p 121-186.

Thomas, J B, 1970, Illinoian-Wisconsin Pleistocene deposits at Eaton, Ohio: Geol Soc America Bull, v 81, p 3433-3436. 